ISSN 0258-7122

Bangladesh J. Agril. Res. 35(1) : 65-76, March 2010

\title{
COMPARATIVE ECONOMIC ANALYSIS OF BORRWER AND NON- BORROWER BORO RICE FARMERS IN SOME SELECTED SITES OF MYMENSINGH DISTRICT
}

\author{
M. S. K. SARKAR ${ }^{1}$ M. R. HASAN $^{2}$, M. A. FEARDOUS ${ }^{3}$ \\ M. M.H SHUHEL ${ }^{4}$ AND MONIRUZZAMAN ${ }^{5}$
}

\begin{abstract}
The present study has been conducted to examine the differences in input use, costs and returns of the borrower and non-borrower rice farmers. One hundred samples from four villages under Tiishal Upazila of Mymensingh district were selected for the study. The study reveals that borrower farmers used more inputs and attained more returns through higher yield than their counterparts. The yields of rice per hectare were $5260.80 \mathrm{~kg}$ and $4177.34 \mathrm{~kg}$ for the borrower and non-borrower farmers, respectively. The gross returns and net returns were Tk. 41699.03 and Tk. 4475.64, respectively, for the non-borrower farmers and Tk. 51589.53. and Tk. 8821.68, respectively, for borrower farmers. The undiscounted BCRs were 1.73 and 1.12 in case of non-borrower farmers and 1.74 and 1.21 for the borrower ones. The study further reveals that credit could be judged as a vital player to increase higher yield through utilization of necessary production inputs.
\end{abstract}

Keywords: Borrower farmer, non-borrower farmer, cost and return.

\section{Introduction}

Agricultural development is still synonymous with the economic development of Bangladesh. Economic development of the country cannot be achieved unless there is a breakthrough in agriculture sector. Development of agriculture depends upon the use of high yielding variety (HYV) seeds, fertilizer, insecticides, and irrigation which in turn, depend on the massive use of capital. A satisfactory growth in agriculture is a necessary pre-condition for accelerating overall economic growth. The economy of Bangladesh is substantially agro-based.

Agriculture contributes about 21.99 percent of the total gross domestic product (GDP) in 2004-2005, while approximately 12.10 percent of the GDP has been derived from crops and 9.50 percent from rice alone. It provides employment to about 51.69 percent of total population (BER, 2005). Moreover, this sector supplies raw materials to a large number of industries in the country.

${ }^{1}$ Lecturer, Department of Agricultural Economics \& Rural Sociology, Patuakhali Science \& Technology University, Duniki, Patuakhali, ${ }^{2 \& 5}$ Scientific Officer, Bangladesh Agricultural Research Institute, Joydebpur, Gazipur-1701, ${ }^{3}$ Former M.S. Student; Department of Rural Sociology, Bangladesh Agricultural University, Mymensingh ${ }^{4}$ Former M.S. Student; Department of Agricultural Finance, Bangladesh Agricultural University, Mymensingh, Bangladesh. 
At present, agriculture sector is largely dominated by the rice production. Rice, the staple food and major cereal crop of Bangladesh dominates Bangladesh agriculture which occupies more than 73 percent of total cropped area. Basically rice cultivation is the major source of livelihood of the people of Bangladesh and about 82 percent of the total agricultural production comes in the form of rice (BBS, 2004).

Bangladesh ranks fourth among the rice producing countries in the World after China, India and Indonesia. Boro plays an important role in gaining selfsufficiency in food. In terms of area covered, total cultivated area under paddy was 10.77 million hectares and production was accounted for 25.19 million metric tons in 2002/03. But in 1998/99, rice area was 1011 million hectares and production was 23.07 million metric tons (BBS, 2004).

Area and production of Boro and total paddy grown in Bangladesh.

\begin{tabular}{r|c|c|c|c}
\hline \multirow{2}{*}{ Year } & \multicolumn{3}{|c|}{ Boro } & \multicolumn{2}{c}{ Total } \\
\cline { 2 - 5 } & $\begin{array}{c}\text { Area } \\
\text { ‘000’ ha }\end{array}$ & $\begin{array}{c}\text { Production ‘000’ } \\
\text { MT }\end{array}$ & $\begin{array}{c}\text { Area } \\
\text { '000’ ha }\end{array}$ & $\begin{array}{r}\text { Production } \\
\text { ‘000’ MT }\end{array}$ \\
\hline $1998-1999$ & 352 L34 & 10,552 & 10119.84 & 19,905 \\
$1999-2000$ & 3653.44 & 11,027 & 10713.36 & 23,067 \\
$2000-2001$ & 3763.56 & 11,921 & 10812.02 & 25,085 \\
$2001-2002$ & 3772.87 & 11,766 & 10665.18 & 24,300 \\
$2002-2003$ & 3846.15 & 12,222 & 10775.30 & 25,188 \\
\hline
\end{tabular}

Sources: BBS, 2004

Yield variation between borrowed and non-borrowed rice farms is one of the chronic problems of rice production in Bangladesh. The important factor behind this difference could be that the farmers may forgo the sub-optimum investment in agricultural inputs because of the high risk in rice cultivation. Borrower farmers used higher amount of critical inputs and get maximum profit from rice production (Satapathy and Tripathy, 2001).

Credit is one of the important factors influencing substantially the output of agriculture. The performance of the non-borrower rice farmers is lower than those of borrower farmers because of not yet fully utilized the most recent developed rice production technology due to lack of adequate operating capital. Production may respond to the changes in the supply of credit only if the demand for input used in the production process, is influenced by the changes in the supply of credit. But very few studies (Miah, 2006; Rahman, 2008) was conducted their aspect. Keeping all these factors in consideration, the present study attempts to address the aforesaid issues. 


\section{The specific ohjectives of the study are as follows:}

- to determine the input use pattern of Boro rice growers between the borrower and non -borrower;

- to determine the profitability level of Boro rice growers using credit;

- to study the interrelationship between input and output of Boro rice production, and

- to investigate the utilization of credit according to loan size.

\section{Materials and Method}

The study was conducted at four villages named Mothbari, Joida, Badhamia and Alohari (Durgapur) in Trishal Upazila of Mymensingh district where a considerable number of borrower and non-borrower farmers grew Boro paddy. A stratified random sampling technique was followed in this study. At first, two lists of borrower and non-borrower farmers who cultivated Boro paddy was collected from the Bangladesh Krishi Bank (BKB) (Kashigonj Branch) and Upazila Agiicultural Extension Office in Trishal. Then 50 borrower and 50 nonborrower Boro farmers were chosen randomly from each of the two lists. The instruments used for collecting primary information of the study included a structured questionnaire and informal interview. The pre-tested questionnaire included both closed and open-ended questions, which were prepared keeping the objectives of the study in view. The data collection process, took place during March-April 2006. Finally, the collected data were summarized, tabulated and analyzed in accordance with the objectives of the study. In tabular analysis, simple relationships between dependent and independent variables were studied. Farm business analytical techniques, such as enterprise costing gross margin analysis were performed to locate the costs, returns and profitability of the enterprises. In this study, cost and return analyses were done on both variable and total cost basis. For calculating interest on operating capital, the following formula was used:

Interest on operating capital = Operating capital/2 x Rate of interest $\mathrm{x}$ time considered.

To determine the contributions of the important variables in the rice production process, the Cobb-Douglas form of production function was finally estimated because of the best fit of the sample data. After different trial runs. 6 variables were ultimately selected to explain the production of Boro rice of the borrower and the non-borrower rice farmers. Care was taken to avoid multicolinearity. The general model was specified comprehensively in such a way that it could explain adequately the production process of the Boro rice of both types of farmers. To explore the input-output relationship of Boro rice 
production, the selected Cobb-Douglas production model, in its stochastic form may be expressed as:

$\mathrm{Y}=\mathrm{aX}_{1}{ }^{\mathrm{b} 1} \mathrm{X}_{2}{ }^{\mathrm{b} 2} \mathrm{X}_{3}{ }^{\mathrm{b} 3} \mathrm{X}_{4}{ }^{\mathrm{b} 4} \mathrm{X}_{5}{ }^{\mathrm{b} 5} \mathrm{X}_{6}{ }^{\mathrm{b} 6} \mathrm{U}_{1}$

The Cobb-Douglas production function was linearized by transforming it into the following double log or log linear form so that it could be solved by the least square method:

$\log Y=\log a+b_{1} \log X_{1}+b_{2} \log X_{2}+b_{3} \log X_{3}+b_{4} \log X_{4}+b_{5} \log X_{5}+$ $\mathrm{b}_{6} \log \mathrm{X}_{6}+\mathrm{U}_{\mathrm{i}}$

Where,

$\mathrm{Y}=$ Return from rice (Tk./ha)

$\mathrm{a}=$ Constant or intercept of value

$\mathrm{X}_{1}=$ Cost of human labour (Tk./ ha)

$\mathrm{X}_{2}$ Cost of seeds (Tk./ha)

$\mathrm{X}_{3}=$ Cost of fertilizer (Tk./ ha)

$\mathrm{X}_{4}$ Cost of insecticides (Tk./ ha)

$\mathrm{X}_{5}=$ Cost of irrigation (Tk./ha)

$\mathrm{X}_{6}=$ Cost of power tiller (Tk./ ha)

$\mathrm{U}_{\mathrm{i}}=$ Errorterm

\section{Results and Discussion}

\section{Socio-economic characteristics of the sample farmers}

Socio-economic characteristics of the decision makers are important in the sense that these profoundly influence their crop production decision i.e., crop selection, technology choice, credit requirement, selection of the credit institutions and overall farm decision-making. Thus, information relating to entrepreneur's age, educational level, farm size, occupation etc. help in understanding farmers' environment and decision making ability of the producer.

Table 1 reveals that out of the total borrower rice growers, 72 percent fell into age group of 15 to 55 years and 28 percent fell into above 55 years of age group. In case of non-borrower rice farmers, 66 percent belonged to the age group of 15 to 55 years. 28 percent of the borrower farmers had no formal education. Men who do not know how to write a letter were considered as illiterate. In case of non-borrower rice growers, 64 percent had formal education. Table 1 also shows that in the study area, average farm size was 0.51 and 0.46 hectares for borrower and non-borrower farmers, respectively. Average annual income was Tk. 76,432 and Tk. 74,977 for the borrower and non-borrower 
farmers, respectively. About 81 and 84 percent of the total income for the borrower and non-borrower farmers came from agriculture, respectively.

Table 1. Socio-economic characteristics of the sample farmers.

\begin{tabular}{lll}
\hline \multicolumn{1}{c}{ Characteristics } & \multicolumn{1}{c}{ Borrower } & Non-borrower \\
\hline $\begin{array}{ll}\text { Age group (year) } \\
<15\end{array}$ & 00 & 00 \\
15 to 55 & $36(72)$ & $33(66)$ \\
Above 55 & $14(28)$ & $17(34)$ \\
\hline Total & $50(100)$ & $50(100)$ \\
\hline Literacy level: & & \\
Illiterate & $14(28)$ & $18(36)$ \\
Primary & $20(40)$ & $13(26)$ \\
Secondary & $13(26)$ & $17(34)$ \\
Higher secondary and above & $3(6)$ & $2(4)$ \\
\hline Total & $50(100)$ & $50(100)$ \\
\hline Farm size (ha): & & \\
Average farm size & 0.51 & 0.46 \\
Occupation: & & \\
Agriculture & $37(74)$ & $41(82)$ \\
Agriculture +Business & $10(20)$ & $2(14)$ \\
Others & $3(6)$ & $50(100)$ \\
\hline Total & $50(100)$ & $62327.00(84)$ \\
\hline Farmer group: & & $12650.00(16)$ \\
Farm income (Tk./year) & $61792.00(81)$ & $74977.00(100)$ \\
Non-farm income (Tk./year) & $14640.00(19)$ & \\
\hline Total (Tk./year) & $76432.00(100)$ & \\
\hline
\end{tabular}

Figures in the parentheses indicate percentages

Source: Field Survey, 2006

\section{Cost of Boro rice Production}

Variable Costs

\section{Cost of human labour}

The rate of a man-day was varied from Tk. 70 to Tk. 150 during the cropping period. It was higher in the period of harvest (average Tk. 150) and lowest in the period of weeding (average Tk. 70). The total cost of human labour was, 
therefore, Tk. 14063.98 per acre for borrower rice farms and Tk. 11490.24 for non-borrower rice farms (Table 3).

Table 2. Cash cost (Tk./acre) of the respondents in producing rice.

\begin{tabular}{l|l|l|l|l}
\hline \multirow{2}{*}{ Cost items } & \multicolumn{3}{c|}{ Borrower } & \multirow{2}{*}{ Non-borrower } \\
\cline { 2 - 4 } & \multicolumn{1}{c}{$\begin{array}{c}\text { Self-financing } \\
(\mathrm{SF})\end{array}$} & $\begin{array}{c}\text { Credit } \\
\text { financing (CF) }\end{array}$ & Total & \\
\hline Human labour (hired) & 2841.68 & 2898.72 & 5740.40 & 6097.81 \\
& $(14.97)$ & $(15.27)$ & $(30.24)$ & $(35.89)$ \\
Animal \& mechanical & 2353.72 & - & 2353.72 & 2360.90 \\
power & $(12.39)$ & & $(12.39)$ & $(13.89)$ \\
Seed & 459.17 & - & 459.17 & 417.85 \\
& $(2.42)$ & & $(2.42)$ & $(2.46)$ \\
Fertilizer and manure & 1333.16 & 1893.03 & 3226.19 & 2279.34 \\
& $(7.02)$ & $(9.97)$ & $(16.99)$ & $(13.41)$ \\
Insecticides & 119.25 & 644.55 & 763.80 & 537.97 \\
& $(0.63)$ & $(3.39)$ & $(4.02)$ & $(3.17)$ \\
Irrigation & 3095.87 & 3346.85 & 6442.72 & 5297.40 \\
& $(16.31)$ & $(17.63)$ & $(33.94)$ & $(31.18)$ \\
\hline Total & 10202.46 & 8783.15 & 18985.61 & 16991.23 \\
& $(53.74)$ & $(46.26)$ & $(100)$ & $(100)$ \\
\hline
\end{tabular}

Figures in the parentheses indicate percentages

Soure: Field Survey, 2006

\section{Cost of seeds}

Farmers in the study area used both families supplied and purchased seeds for producing Boro paddy. Cost of seeds for borrower farms was borne by selffinancing (SF) and covered 2.42 percent of the total cash costs (Table 2). Cost of seeds for non-borrower rice farms estimated Tk. 1013.69, which was 2.46 percent of the total cash cost (Table 2) and 2.72 percent of the total cost (Table 3).

\section{Cost of fertilizers and manure}

Farmers used various kinds of fertilizers in the study area. All the fertilizers were purchased. In case of borrower rice farms, cost of fertilizer and manure was Tk. 4291.38, which covered 16.99 percent of the total cash costs (Table 2) and 10.03 percent of the total costs (Table 3). In the case of borrower rice farmers per hectare, 7.02 percent and 9.97 percent of the total cash cost of the fertilizer and manure was financed by SF and credit financing (CF), respectively. Fertilizer and manure cost was Tk.. 2990.92, which covered 13.41 percent of total cash cost (Table 2) and 8.04 percent of the total costs (Table 3 ) in case of non-borrower iice farmers.

\section{Cost of insecticides}


The sample farmers bought insecticides from the village dealers. Cost of insecticides was found to be Tk. 763.80 and Tk. 537.97 covering 1.79 percent and 1.44 percent of the total costs in case of borrower and non-borrower farms, respectively (Table 3 ). Per hectare 0.63 percent and 3.39 percent of the total cash cost of insecticides was borne by SF and CF fund, respectively, in case of borrower rice farms (Table 2).

\section{Cost of animal and mechanical power used}

In the study area, power tiller was mainly used for land preparation. Cost of power tiller use per hectare was calculated as Tk. 2650.24 and Tk. 2619.04 for borrower and non-borrower rice farms, respectively, which covered 6.20 percent and 7.04 percent of the total costs in the case of borrower and non-borrower rice farms, respectively (Tables 3).

\section{Cost of irrigation}

In the study area, all the sample farmers had to depend on Deep tube-well (DTW) and shallow tube-well (STW) for irrigation. Most of the farmers used purchased water for irrigation. The average irrigation costs were Tk. 644.72 and Tk, 5297.36 per hectare for borrower and non-borrower rice farmers, respectively. Borrower farmers irrigated more than non-borrower rice farmers. In the case of borrower rice farmers, 16.31 percent and 17.63 percent of the total cash cost of the irrigation cost was borne by SF and CF fund, respectively (Table 2). Cost of irrigation was 15.06 percent of the total cost for the borrower farmers and 14.23 percent of the total cost for the non-borrower rice farms in the study area (Table 3).

\section{Interest on operating capital}

Interest on operating capital was determined on the basis of opportunity cost principle. The operating capital actually represented the average operating costs over the period because all costs were not incurred at the beginning or at any fixed time. The costs were incurred throughout the whole production period. In this study, interest on operating capital was charged for a period of four months at the rate of Tk. 6.50 percent per annum. Interest on operating capital charged on cash cost only, such as human labour, animal labour, power tiller, seeds, manure, fertilizers, insecticides, inigation, etc. Interest on operating capital per hectare was estimated Tk. 311.64 and Tk. 184.06 for the borrower and non-borrower rice farms, respectively (Table 3). 
Table 3. Total cost (Tk./ha) of the respondents in producing rice.

\begin{tabular}{|c|c|c|c|c|}
\hline \multirow[b]{2}{*}{ Cost items } & \multicolumn{3}{|c|}{ Borrower } & \multirow[b]{2}{*}{ Non-bonower } \\
\hline & $\begin{array}{l}\text { Self financing } \\
\text { (SF) }\end{array}$ & $\begin{array}{l}\text { Credit financing } \\
(\mathrm{CF})\end{array}$ & Total & \\
\hline \multicolumn{5}{|c|}{ A. Variable cost } \\
\hline \multicolumn{5}{|l|}{ Human labour: } \\
\hline Own & 8323.58 & - & 8323.58 & 5392.43 \\
\hline Hired & 2841.68 & 2898.72(6.77) & 5740.40 & 6097.81 \\
\hline Total & $11165.26(26.11)$ & 2898.72(6.77) & 14063.98(32.88) & $11490.24(30.87)$ \\
\hline \multicolumn{5}{|l|}{ Seed: } \\
\hline Own & 693.92(1.62) & - & 693.92(1.62) & 595.84 \\
\hline Hired & 459.17(1.08) & - & 459.17(1.08) & 417.85 \\
\hline Total & 1133.09(2.70) & - & 1133.09(2.70) & $1013.69(2.72)$ \\
\hline \multicolumn{5}{|c|}{ Fertilizer \& manure: } \\
\hline Own & 1065.19 & - & 1065.19 & 691.82 \\
\hline Hired & 1333.16 & $1893.03(4.42)$ & 3226.19 & 2279.34 \\
\hline Total & 2398.35(5.61) & 1893.03(4.42) & 4291.38(10.03) & 2990.92(8.04) \\
\hline Insecticides & $119.25(0.28)$ & 644.55(1.51) & 763.80(1.79) & $537.97(1.44)$ \\
\hline \multicolumn{5}{|c|}{ Animal \& mech. power: } \\
\hline Own & 296.92 & - & 296.92 & 258.14 \\
\hline Hired & 2353.32 & - & 2353.32 & 2360.90 \\
\hline Total & $2650.24(6.20)$ & - & $2650.24(6.20)$ & 2619.04(7.04) \\
\hline Irrigation & 3095.87(7.24) & 3346.85(7.82) & 6442.72(15.06) & 5297.36(14.23) \\
\hline Interest on OC & $311.64(0.73)$ & - & 311.64(0.73) & $184.06(0.49)$ \\
\hline $\begin{array}{l}\text { Total variable } \\
\text { cost }\end{array}$ & 20893.71(48.85) & 8783.15(20.54) & 29676.85(69.39) & 24133.48(64.83) \\
\hline \multicolumn{5}{|c|}{$\underline{\text { B. Fixed cost }}$} \\
\hline Land use cost & - & - & $13091.00(30.61)$ & 13091.00(35.17) \\
\hline $\begin{array}{l}\text { Total fixed } \\
\text { cost }\end{array}$ & - & - & 13091.00 & 13091.00 \\
\hline $\begin{array}{l}\text { Total costs } \\
(\mathrm{A}+\mathrm{B})\end{array}$ & - & - & 42767.85(100) & $37224.48(100)$ \\
\hline
\end{tabular}

Source: Field survey, 2006

Note= Figure within parentheseis indicate percentage

\section{Fixed Costs}

\section{Land use cost}

In this study, land use cost was estimated by calculating interest on the value of land for the cropping period of four months. The average land use cost per 
hectare was Tk. 13091.00 and Tk. 13091.00 for the borrower and non-borrower rice farms, respectively (Table 3).

\section{Total cost}

Summation of per hectare fixed and variable costs gave the per hectare total cost of producing rice which stood at Tk. 42767.85 and Tk. 37224.48 for the borrower and non- borrower rice farms, respectively (Table 3).

\section{Profitability of rice production}

Per hectare rice produced in borrower and non-borrower farms were $5260.80 \mathrm{~kg}$ and $4177.34 \mathrm{~kg}$. These also produced $4116.67 \mathrm{~kg}$ and $3812.84 \mathrm{~kg}$ straw, which valued at Tk. 5557.50 and Tk. 5147.33, respectively. The gross returns from borrower and non-borrower rice farms were estimated Tk. 51539.53 and Tk. 41699.03 per acre, respectively (Table 4).The average market prices of rice and by-product were Tk. 8.75 and Tk. 1.35 per kg, respectively. The total costs of rice were estimated Tk. 42767.85 and Tk. 37224.48 for the borrower and nonborrower farms, respectively (Table 4). Per hectare net returns of borrower and non-borrower rice farms were calculated at Tk. 8821.68 and Tk. 4475.64 (Table 4). Undiscounted BCRs, for sample farmers were found to be 1.74 and 1.21 on variable and total cost basis in the case of borrowing rice farms (Table 4). Again in case of non-borrowing rice farms, the undiscounted BCRs were 1.73 and 1.12 on variable and total cost basis (Table 4).

Table 4. Summary results of costs and returns of the borrower and non-borrower farmers.

\begin{tabular}{l|ll}
\hline \multirow{2}{*}{\multicolumn{1}{c|}{ Particulars }} & \multicolumn{2}{c}{ Amount (Tk./acre) } \\
\cline { 2 - 3 } & \multicolumn{1}{|c}{ Borrower } & \multicolumn{1}{c}{ Non-borrower } \\
\hline Yield of rice (kg/ha) & 5260.80 & 4177.34 \\
Yield of by-product (kg/ha) & 4116.67 & 3812.84 \\
Value of rice & 46032.03 & 36551.70 \\
Value of by-product & 5557.50 & \\
Gross return & 51589.53 & 41699.03 \\
Variable cost & 29676.85 & 24133.48 \\
Fixed cost & 13091.00 & 13091.00 \\
Gross cost & 42767.85 & 37224.48 \\
Net return & 8821.68 & 4475.64 \\
Gross margin & 21912.68 & 17566.64 \\
BCR (variable cost basis) & 1.74 & 1.73 \\
\hline
\end{tabular}


BCR (total cost basis)

1.21

1.12

Source: Field survey, 2006

\section{Contribution of factors inputs to Boro rice production}

The va1ue of the coefficient of determination $\mathrm{R}^{2}$ were 0.95 for borrowers' rice farms and 0.94 for non-borrower rice farms. It indicates that around 95 percent and 94 percent of the total variation of gross returns. F-ratios in the case of borrower and non-borrower rice farms were 180.96 and 151.68, both of which were significant at 1 percent level of probability i.e., all the included variables were important for explaining the variation in returns. It implies good fit of the model (Table 5).

\section{Input-output relationship}

According to the fmdings of the study factors like seed $\left(X_{1}\right)$, fertilizer $\left(X_{3}\right)$, insecticides $\left(\mathrm{X}_{4}\right)$ irrigation cost $\left(\mathrm{X}_{5}\right)$ and power tiller use $\left(\mathrm{X}_{6}\right)$ were positive and significant for borrower rice farmers. It indicates that a 1 percent increase in seed $\left(\mathrm{X}_{2}\right)$, fertilizer $\left(\mathrm{X}_{3}\right)$, insecticides $\left(\mathrm{X}_{4}\right)$ irrigation cost $\left(\mathrm{X}_{5}\right)$ and power tiller use $\left(\mathrm{X}_{6}\right)$ keeping all other factor constant, would result an increase in the gross return by $0.25,0.21,0.23,0.25$ and 0.07 percent, respectively. In case of non-borrower rice farmers, coefficient of human labour $\left(\mathrm{X}_{1}\right)$, fertilizer $\left(\mathrm{X}_{3}\right)$ and irrigation cost $\left(\mathrm{X}_{5}\right)$ were positive and significant. Coefficient of insecticides $\left(\mathrm{X}_{4}\right)$ was found negative and not significant in case of non-borrower rice farmers (Table 5).

Table 5. Estimated values of coefficients and related statistics.

\begin{tabular}{l|l|l|l|l}
\hline \multirow{2}{*}{\multicolumn{1}{c}{ Explanatory variables }} & \multicolumn{2}{c|}{ Borrower farmers } & \multicolumn{2}{c}{ Non-borrower farmers } \\
\cline { 2 - 5 } & \multicolumn{1}{c}{$\begin{array}{c}\text { Estimated } \\
\text { values }\end{array}$} & t-values & $\begin{array}{c}\text { Estimated } \\
\text { values }\end{array}$ & t-values \\
\hline Intercept & -1.52 & -1.01 & -2.19 & -1.84 \\
Human labor $\left(\mathrm{X}_{1}\right)$ & $0.04(0.18)$ & 0.83 & $0.34(0.13)$ & 4.99 \\
Seed $\left(\mathrm{X}_{2}\right)$ & $0.25^{* *}(0.13)$ & 2.52 & $0.07(0.01)$ & 1.87 \\
Fertilizer $\left(\mathrm{X}_{1}\right)$ & $0.21^{*}$ & 1.95 & $0.33^{* *}$ & 3.48 \\
Insecticides $\left(\mathrm{X}_{4}\right)$ & $(0.13)$ & $(0.07)$ & -1.75 \\
Irrigation cost $\left(\mathrm{X}_{5}\right)$ & $0.23^{* *}(0.09)$ & 2.54 & $-0.14(0.05)$ & 4.86 \\
Power Tiller use $\left(\mathrm{X}_{6}\right)$ & $0.25^{* *}(0.09)$ & 3.60 & $0.41^{* *}(0.10)$ & 4.69 \\
\hline $\mathrm{R}^{2}$ & $0.07^{*}$ & 2.14 & 0.03 & $(0.19)$ \\
F-Ratio & $(0.14)$ & & 0.94 & 0.69 \\
\hline
\end{tabular}

Nate: $* *=$ Significant at 1 percent level, *Significant at 5 percent level 
Figures in the parenthesis indicate the standard error

\section{Credit utilization pattern}

Credit can play a significant role $\mathrm{m}$ increasing farm productivity and income. The borrowers have spent their loaned money broadly for the agricultural and nonagricultural purposes. It was found in the present study that the borrowers invested credit mainly on five major items. It is apparent that percentage of total loaned money utilized for agricultural purposes was about 44.77 percent comprises 14.43 percent, 1.06 percent. 9.42 percent. 3.19 percent and 16.67 percent for wage of hired human labour, seed/seedlings, manure and fertilizer, insecticides and bearing charge of irrigation water, respectively. Table 6 also indicates that in irrigation purpose, highest amount of credit was utilized and it was 16.67 percent of the total credit fund. It is evident from this study that irrigation is very crucial for Boro rice production. The borrower farmers in study area used about 55.23 percent of their credit for non-agricultural purposes. As, their economic condition was so poor, they used their credit money in some nonagricultural purposes viz., food consumption, purchase of cloth. educational expenses, medical expenses, repayment of old debt and so on (Table 5).

Table 6. Use of credit by the borrower farmers.

\begin{tabular}{l|l|l}
\hline \multicolumn{1}{c}{ Purpose: Agriculture } & \multicolumn{1}{c}{ Amount (Tk.) } & \multicolumn{1}{c}{ Percent of credit } \\
\hline \multicolumn{1}{c}{ Wage purpose } & 1173.57 & 14.43 \\
Seed/seedling & 86.00 & 1.06 \\
$\quad$ Manure and fertillzer & 766.41 & 9.42 \\
Insecticides & 260.00 & 3.19 \\
$\quad$ Trrigation & 1355.00 & 16.67 \\
\hline Total & 3640.98 & 44.77 \\
Non-agricultural purpose & 4492.00 & 55.23 \\
Grand total & 8132.98 & 100 \\
\hline
\end{tabular}

Source: Field survey, 2006

\section{Conclusions and Recommendations}

The level of productivity was much higher in case of borrower farmers due to the fact that the borrowers had used higher amount of inputs in MV Boro production as compared to non-borrower farmers which enabled them to obtain higher yield. The yield was found 5.30 and 4.20 t/ha for borrower and non-borrower farmers respectively. Both borrowed and own fund can be used in rice production. As regards optimization of resources, the credit recipients could get maximum profit through optimum use of credit. The non-borrower farmers can also allocate their 
resources optimally by higher investment from own fund through increase their non-farm income. Borrower farmers used almost $45 \%$ of the credit for productive purposes which help them to earn more income Adequate amount of credit support can be very helpful to the farmers for increasing efficiency in resource use by being able to apply more inputs in Boro production.

Based on the findings, following recommendations can be made:

i. Traditional cultural practices are being followed by the farmers, so it is necessary to provide information regarding proper time of sowing seed rate, fertilizer dose, etc.

ii. It may be difficult to cultivate this crop for the poor/small farmers as it required higher amount of cash. Thus, emphasis should be given to reduce cash cost through input subsidy. In other way, capital may be supplemented to the poor/small farmers for Boro rice cultivation through credit giving agencies with low interest rates.

iii. DAE and other related institutions should make hybrid seed available in time to the farmers as seed played a significant role on yield.

\section{References}

Bangladesh Bureau of Statistics. 2004. Statistical Year Book of Bangladesh. Ministry of Planning, Government of the People's Republic of Bangladesh.

Bangladesh Economic Review. 2005. Economic Division, Minisliy of Finance, Government of People's Republic of Bangladesh, Dhaka

Satapathy S.K. and S. Tripathy. 2001. An Economic Analysis of Borrower and Nonborrower Rice Farmers in Cuttak District of Orissa, Indian Journal of Agricultural Economics 56(1).pp. 89-99

Miah M. A. K, A. K. M. Ashrafulalam and A. H. M. A. Rahman. 2006. Jmpact of Agricultural Credit on MV Boro Rice Cultivation in Bangladesh. Journal of Agriculture and Rural Development 4(1\&2): 161-168.

Rahman, M. S. 2008. Impact of Micro Credit on Boro Rice Production in Nilphamari District, Bangladesh. Eco-friendly Agriculture Journal 1(2). BRRI, Gazipur, Bangladesh. 